\title{
THE CHINESE OF INDONESIA AND THE DEVELOPMENT OF THE INDONESIAN LANGUAGE
}

\author{
Dédé Oetomo
}

\section{Introduction: Malay, Indonesian and the Chinese of Indonesia ${ }^{1}$}

Since early in the formation of their communities, the peranakan or baba Chinese $^{2}$ of the Malay Archipelago have communicated among themselves in local languages and in various dialects of the Malay language. ${ }^{3}$ They have also produced literature in local languages

This article was written while I was a Fulbright scholar-in-residence attached to the 1990 Southeast Asian Studies Summer Institute at Cornell. I would like to thank the institute, particularly its director, John Wolff, for inviting me to present the paper at the symposium and, more generally, to attend the institute. Thanks are also owed the United States Information Agency, the Council for International Exchange of Scholars, and the American-Indonesian Exchange Foundation for providing the Fulbright grant. Claudine Salmon and Jim Collins helped me shape many of the ideas in this paper, and John Wolff gave extensive and incisive comments on the first draft; to them goes my sincere gratitude. Of course, I alone am responsible for what I have written.

${ }^{1}$ The term Malay here refers to all dialects of Malay before the rise of the nationalist movement in Indonesia, whereas Indonesian refers to varieties that developed thereafter.

${ }^{2}$ The term peranakan, or baba, Chinese, is used here to refer to descendants of unions between male Chinese immigrants who came to the Indies before the end of the nineteenth century and local women or women born from such relationships. Culturally, the peranakan or baba have adopted numerous local elements. The other subcategory of Indonesian Chinese, the totok, consists of immigrants who came after the turn of the century and their descendants. Totok culture shows its Chinese roots more prominently. Cf. G. William Skinner, "The Chinese Minority," in Indonesia, ed. Ruth T. McVey (New Haven: HRAF Press, 1963), pp. 103-10. Although the peranakan use Malay and/or a local language, most totok use a Chinese dialect or, until very recently, a local language. See Dédé Oetomo, "Multilingualism and Chinese Identities in Indonesia," in Changing Identities of the Southeast Asian Chinese since World War II, ed. Jennifer Cushman and Wang Gungwu (Hong Kong: Hong Kong Univ. Press, 1988), pp. 97-106.

${ }^{3}$ Claudine Salmon, Literature in Malay by the Chinese of Indonesia: A Provisional Annotated Bibliography (Paris: Editions de la Maison des Sciences de l'Homme, 1981), p. 15, for example, cites the seventeenth-century Chinese text Dongxi yangkao as mentioning the existence of Chinese who "acted as secretaries and interpreters for the Sultan of Banten (West Java), which suggests that some of them, at least, learned the local language fairly quickly" (Dongxi yangkao [Kyoto: Chubun shuppan sha, 1969], 3: 29). Furthermore, she quotes Ong Tae Hae (Wang Dahai), who in his Haidao yizhi mentions that "when the Chinese remain abroad for several generations, without return- 
and starting in the second half of the nineteenth century, have published even more literature in Malay. 4

Malay, renamed Indonesian, was declared the national language of Indonesia in 1928 and has, since the rise of the nationalist movement, the Japanese occupation, and Indonesian independence, acquired an increasingly larger number of speakers among indigenous Indonesians in non-Malay-speaking areas. ${ }^{5}$ Many people, however-historians, linguists, and other social scientists, as well as average Indonesians-have failed to recognize that before Malay became a code in the daily speech of the majority of non-Malay-speaking Indonesians in the postindependence era, it had already been used extensively by an immigrant minority. ${ }^{6}$

The discourse on the Chinese of Indonesia is often marked by the designation of an "ethnically separate" dialect of Malay, "Chinese Malay" (Melayu Tionghoa, Melayu Cina). Most present-day Indonesians, including ethnic Chinese, believe that there is indeed a socalled Chinese Malay dialect. ${ }^{7}$ What they have in mind is usually two quite different things. First, they are thinking of the language used in works in Malay by Chinese authors from the second half of the nineteenth century to the early $1960 \mathrm{~s}^{8}$ and, perhaps more familiar to them, the language used in kungfu (silat) stories translated from Chinese or originally written in Malay/Indonesian. ${ }^{9}$ Second, in Javanese-speaking areas, they have in mind the mixture of Javanese and Malay/Indonesian that they perceive to be spoken exclusively by ethnic Chinese but that actually is also spoken by other ethnic Asians, Eurasians, and indigenous Indonesians connected in some way with the Chinese. ${ }^{10}$

The term "Chinese Malay" is really a misnomer. There may be a continuity between "Chinese Malay" and modern Indonesian, especially because the former was also used in

ing to their native land, they frequently cut themselves off from the instructions of the sages; in language, food and dress they imitate the natives and studying foreign books, they do not scruple to become Javanese, when they call themselves Islam (Sit-lam)." Salmon, Literature in Malay, pp. 15-16; Ong Tae Hae, The Chinaman Abroad: A Desultory Account of the Malay Archipelago Particularly of Java, trans. W. H. Medhurst (Shanghai: Mission Press, 1849).

${ }^{4}$ Regarding literature in local languages, see Gilbert Hamonic and Claudine Salmon, "La vie littéraire et artistique des Chinois Peranakan de Makassar (1930-1950)," Archipel 26 (1983): 143-78; Claudine Salmon, "A Note on Javanese Works Derived from Chinese Fiction," in Literary Migrations: Traditional Chinese Fiction in Asia (17-20th Centuries), ed. Claudine Salmon (Beijing: International Culture Publishing Corporation, 1987), pp. 375-94; Liang Liji, "Sastra Peranakan Tionghoa dan Kehadirannya dalam Sastra Sunda," Archipel 34 (1987): 165-79. For studies on literature in Malay, cf. Nio Joe Lan, Sastera Indonesia-Tionghoa (Djakarta: Gunung Agung, 1962); Salmon, Literature in Malay; Leo Suryadinata, "Sastra Peranakan di Indonesia," in Kebudayaan Minoritas Tionghoa di Indonesia, ed. Leo Suryadinata, trans. Dédé Oetomo (Jakarta: Gramedia, 1988), pp. 100-118.

${ }^{5}$ See, for example, Sutan Takdir Alisjahbana, "Bahasa Indonesia," in Dari Perjuangan dan Pertumbuhan Bahasa Indonesia: Kumpulan Esai 1932-1957, (Jakarta: Dian Rakyat, 1978), pp. 20-53.

${ }^{6}$ It should be pointed out that the Chinese were not the only immigrant community to speak Malay among themselves; the Dutch and Eurasians and other so-called Foreign Orientals spoke it too.

${ }^{7}$ Some Indonesians even call it "Chinese language" (bahasa Tionghoa, bahasa Cina).

${ }^{8}$ Cf. n. 5.

${ }^{9}$ See Salmon, Literature in Malay, 1981, passim; and Leo Suryadinata, "Postwar Kungfu Novels in Indonesia: A Preliminary Survey," in Salmon, Literary Migrations, pp. 623-55.

${ }^{10}$ In Javanese-speaking areas, one can perceive a speech continuum from pure Javanese all the way to standard Indonesian, with different varieties of Javanese and Malay/Indonesian mixtures in between. In general, the more formal and polite the situation is, the more Malay/Indonesian forms and the fewer Javanese forms are employed. In fact, in formal situations, the Malay variety used resembles very closely written "Chinese Malay." 
the written discourse of members of ethnic groups besides the Chinese in the colonial period and well into the postindependence era.

Although no one refers in the literature to spoken, mixed Javanese-Malay, in some literature that can rectify the myth of a "Chinese Malay," two facts are pointed out:"11 (1) the daily language of Malay-speaking Chinese varies dialectally from region to region, so that one cannot speak of one dialect of Malay used by ethnic Chinese everywhere in the archipelago; and (2) there is little difference between the local dialect of the Malay-speaking Chinese and other local Malay speakers (although this fact needs empirical investigation).

Here the goal is, first, to reinforce the argument for a general urban pre-Indonesian Malay ${ }^{12}$ used by all ethnic groups in the Netherlands Indies by examining samples of written language found in periodicals and monographs produced by both indigenous and Chinese authors from the turn of the century up to the 1950s (see app. 1). ${ }^{13}$ While arguing for a general urban Malay, I will attempt to explain the differences, some subtle and others not so subtle, that exist at a subdialectal level between the various varieties of the regions and those of different authors.

Second, I will point out the dynamics of the development of different varieties of Malay/Indonesian, by looking at the written language used by indigenous Indonesians and ethnic Chinese in different periods. By looking at the different contexts of language use, one can better appreciate the apparent differences between the variety used by indigenous Indonesians and that used by ethnic Chinese. More recent developments in Indonesian show that the use of Malay/Indonesian has always gone hand in hand with the development of a modern, cosmopolitan, bourgeois culture.

\section{A Grammatical Sketch of Pre-Indonesian Malay}

An examination of the grammar of written pre-Indonesian Malay (PIM), paying careful attention to the possible variations in language usage found in the samples, will illustrate how different the dialect is from standard Malay/Indonesian. The latter is the product of language engineering by the colonial linguistic establishment and, later, by similar agencies, which are often continuations of the former, set up by the Republic. The phonology, inasmuch as it can be gathered from the orthography and from older speakers' pronunciations, and an examination of the morphology and syntax as well as some vocabulary items will

11 See Sutan Takdir Alisjahbana, "Kedudukan Bahasa Melayu-Tionghoa," in Dari Perjuangan, pp. 57-63; Armijn Pané, "Het Chineesch-Maleisch en het Indonesisch," Sin Po wekelijksche editie, 13: 661, (30 xi 1935), 25-26; Pramoedya Ananta Toer, ed., Tempo Doeloe: Antologi Sastra Pra-Indonesia (Jakarta: Hasta Mitra, 1982), pp. 1-16; Claudine Salmon, "La notion de sino-malais est-elle pertinente d'un point de vue linguistique?" Archipel 20 (1980): 177-86 (an English translation may be found in Salmon, Literature in Malay, pp. 115-22).

${ }^{12}$ I am grateful to Ben Anderson for pointing out the designation "urban" for the variety of Malay discussed here. The term pre-Indonesian was first used by Pramoedya Ananta Toer (see, for example, his introduction to Tempo Doeloe, pp. 1-16, where he also uses the term lingua franca Malay).

${ }^{13}$ See the list of the materials scanned at the end of this article. The samples were selected according to their availability in my personal collection as well as that of the Cornell University library Echols Collection on Southeast Asia. They were further selected according to place of publication (Java or the Outer Islands) and for historical moments when one might expect to see a major change in language use, such as the establishment of the Balai Poestaka/Commissie voor de Volkslectuur colonial state publishing house (1908), the Japanese occupation (1942-1945), the proclamation of independence and independence war (1945-1949), and the transfer of sovereignty from the Dutch (1949). I ended the scan in the 1950 s because the decade saw the start of the development of a distinct variety of Indonesian in which one can no longer discern any differences between the styles of indigenous Indonesians and ethnic Chinese in the formal written language. 
show that (1) in general, a Malay of urban centers is used by different ethnic groups, especially when one compares it to other varieties of Malay used elsewhere; (2) one can also discern subdialectal differences, especially through loanwords from the languages originally used by each ethnic group; and (3) the influence of language standardization was felt in the written language of indigenous authors and of Chinese authors writing for indigenous or general publications after the establishment of a standardized system of spelling (1901) and the Balai Pustaka (1908) but was not apparent in the writings of most Chinese authors until after Indonesian independence (1949). However, even a cursory glance at the spoken language shows that old habits die hard; one still finds older speakers of Indonesian speaking with the grammar of PIM, although their vocabulary has come to include modern items.

\section{The Phonology and Orthography of Pre-Indonesian Malay}

Although audio recordings of pre-Indonesian Malay are not available, the dialect can be deduced from the orthography and the pronunciation of most speakers of modern Indonesian in Java. All of the authors use quite consistent spelling systems, although these may differ slightly from author to author or from publication to publication. If one compares the pronunciation of the large majority of speakers of modern Indonesian in Java, for example, to the orthography, one realizes that not much has changed, especially in the language of older speakers or in the informal variety spoken by younger speakers.

Some peculiarities of different varieties of PIM are apparent. Although the sounds themselves are shared by the different varieties, the way they are arranged in syllables (the phonotactics) shows interesting differences from standard Indonesian.

The earliest printed materials do not evidence major differences in the orthography among those written by Eurasians, Chinese, or other Foreign Orientals and indigenous Indonesians. An 1845 Malay primer, ${ }^{14}$ for example, contains samples of letters written in different Indonesian regions from the late eighteenth century to the middle of the nineteenth century. One was written in Yogyakarta on February 22, 1828, apparently by an Arab, and addressed to the Resident of Surakarta, Colonel Naguijs. ${ }^{15}$ The following features, also found in later specimens of PIM are immediately apparent:

1. Where standard Malay (SM) has an $h$ at the end, PIM does not, for example, soeda (SM soedah), "already";16 kasie (SM kasih) "give"; bolee (SM boléh), "be allowed to"; Roepiea (SM Roepiah), "name of currency"; lebeenja (SM lebihnja), "the rest"; tana (SM tanah), "land." Interestingly, in one instance, the writer does use a form ending in $h$, namely, itoelah, "that." Similarly, where SM has an initial $h$, PIM does not in some forms, for example, at $i$ (SM hati), "liver, heart, feelings."

2. Where SM has a final au, PIM has oe, at least in some words, for example, kaloe (SM kalau), "if, when."

3. Where $S M$ has a syllable ending in $a C$, where $C$ is a consonant, PIM has a syllable ending in $e C$ in many forms, for example, the suffix -ken (SM -kan), "transitivitizing/causativebenefactive suffix"; dalem (SM dalam), "inside"; dengen (SM dengan), "with"; patjek (SM padjak), "tax"; dapet (SM dapat), "obtain, gain"; dateng (SM datang), "come"; harep (SM

\footnotetext{
${ }^{14}$ A. Meursinge, Maleisch leesboek voor eerstbeginnenden en meergevorderden, pt. 2 (Leiden: S. en J. Luchtmans, 1845).

${ }^{15}$ Meursinge, Maleisch leesboek, pp. xxviii-xxx.

${ }^{16}$ The spelling of standard Malay/Indonesian follows that of Van Ophuijsen (1901); cf. Ch. A. van Ophuijsen, Kitab Logat Melajoe: Woordenlijst voor de Spelling der Maleische Taal met Latijnsche Karakter (Batavia: Landsdrukkerij. 1903).
} 
harap), "hope." However, some forms are spelled in the same way as in SM, for example, saban, "each, every."

4. On the other hand, where SM has $e$, especially in prefixes, PIM has $a$ in some forms, for example, kapada (SM kepada), "to"; barnama (SM bernama), "be named"; bartemoe (SM bertemoe), "meet"; ampat (SM empat), "four"; katiega (SM ketiga), "third"; kaampat (SM keëmpat), "fourth"; sarta (SM serta), "as well as"; salama lamanja (SM selama-lamanja), "as long as possible"; maningalken (SM meninggalkan), "abandon"; manariema (SM menerima), "accept"; kaloear (SM keloear), "go out," mengartie (SM mengerti), "understand."

5. Where SM has oea, PIM has oewa, such as in oewang (SM oeang), "money"; soewatoe (SM soeatoe), "some kind of."

6. Many forms containing the sequence $-\mathrm{CerV}$ - in SM, where $\mathrm{C}$ is a consonant and $V$ a vowel, appear with the sequence - $\mathrm{Cr} V$ in PIM, such as in priksa (SM periksa), "examine"; negrie (SM negeri), "country."

7. The glottal stop is not indicated in the spelling of some authors, such as in tida (SM tida'), "not," or is represented by the letters $h$ or $k$, such as in perkatahan (SM perkataän), "word, phrase," or tjoetjoek (SM tjoetjoe), "grandchild."

8. Some forms are spelled in ways that are peculiar to PIM, such as njang (SM jang),17 "that, who, which"; koetika (SM ketika), "when (as conjunction)."

The 1828 specimen also contains many peculiar spellings not found in later specimens. When one compares it with other specimens in the primer written in Java, one finds that the previously mentioned spelling conventions are consistently followed. One exception is a letter from Bandung dated August 8, 1829, in which dateng and harep are spelled datang and harap, respectively; however, the orthography is otherwise basically the same as in the letters from Central and East Java and Madura. ${ }^{18}$ It is when one compares these specimens from Java to those from Kupang and Arau Wukan in eastern Indonesia dated 1797 to $1804^{19}$ that one notices some orthographical differences, such as the sound $[\mathrm{u}]^{20}$ inconsistently represented by $u$ such as in tuwan, "sir, lord" and mulija, "noble"; and oe, such as in satoe, "one," and doea, "two"; or SM final $n$ appearing as ng, such as in kapang (SM kapan), "when," and laing (SM lain), "other."

The same features of PIM can still be found in an announcement for the Surabaya-based Soerat Kabar bahasa Melaijoe (January 12, 1856), published by the Eurasian E. Fuhri and aimed at a Chinese audience, ${ }^{21}$ and in excerpts from two Batavian newspapers of 1879: Bintang Barat, April 1 and Pembrita Betawi, February 7.22 Both of the latter were published by Eurasians employing Eurasian, Chinese, and indigenous journalists. However, another announcement from Soerat Chabar Betawie (April 3, 1858) does show one orthographic feature closer to the SM spelling introduced more than forty years later, namely, words such as

\footnotetext{
${ }^{17}$ After the turn of the century, it seems that this spelling was completely replaced by jang, although in spoken language one can hear older speakers pronounce it as njang.

${ }^{18}$ Meursinge, Maleisch leesboek, p. xxxi.

${ }^{19}$ Ibid., pp. xv-xxviii.

20 I am here using symbols of the International Phonetic Association.

${ }^{21}$ Sudarjo Tjokrosisworo, ed., Kenangan Sekilas Sedjarah Perdjuangan Pers Sebangsa (Jakarta: Serikat Perusahaan Suratkabar, 1958), pp. 139-40.

${ }^{22}$ These excerpts are reprinted in issues dated June 11 and June 6, 1990, of the Jakarta-based newspaper Jayakarta; the orthography seems to have been faithfully preserved.
} 
dalam (PIM dalem), "inside"; dengan (PIM dengen), "with"; and menjatakan (PIM menjataken), "declare."23

This was, then, the situation of Malay orthography toward the turn of the century. The orthographic features of works by the Chinese, despite inconsistencies between authors and over time, were generally similar to those of the system just described. Thus, up to the 1900 s, except for a few unusual cases like the letter from Bandung and the announcement from Soerat Chabar Betawie, the orthography of PIM does not show differences based on the ethnicity of the authors.

In 1901, the colonial government introduced the spelling devised by Van Ophuijsen. ${ }^{24}$ Most nongovernmental, indigenous publications, such as the nationalist periodical Kaoem Moeda based in Bandung, complied with the new orthography. In its January 2, 1915, issue, for example, one can read the following:

Soerat kabar "Preanger Bode" soedah membikin pertanjaan demikian [Sanggoepkah Duitschland menjerang ketanah Inggris?], laloe memberi poela djawabannja dengan pandjang lebar bahwa diwaktoe ini beloem boleh diharap jang Duitschland akan bisa menoeroenkan lasjkarnja dengan hasil ditanah Inggris. ${ }^{25}$

The first chief editor of this publication was Abdoel Moeis, some of whose works were published by the state-owned Balai Poestaka, so it is not surprising that Kaoem Moeda complied with the new orthography. But one also cannot help correlating the spelling of words like dengan, "with," diharap, "be expected," akan, "will," and menoeroenkan, "land" with the fact that the publication came out of Bandung (cf. the letter from Bandung).

Nevertheless, from time to time one does find inconsistencies, such as in the annual report of the nationalist organization Boedi Oetomo for 1917-191826 in which on the same page one can find the words mengoeraikan, "expound," and dengen (SM dengan), "with." One interesting case can be found in Mas Marco Kartodikromo's Sair rempah-rempah. ${ }^{27}$ The Semarang-based publisher included an errata sheet (rectificatie) in which the erroneous membitjarakenja, "speak about it," is corrected as membitjarakannja. However, whoever corrected it apparently did not read the Van Ophuijsen manual carefully because he or she also corrected SM karena, "because," and berani, "brave," to PIM krena and brani, respectively.

Moreover, it seems that people's compliance became lax in advertising materials, such as those found in Semaoen's Hikajat Kadiroen. ${ }^{28}$ Although the contents are at least orthographically consistent with the standardized spelling, an advertisement on the last page of the book reads as follows: "Soedara-soedara jang maoe membikin barang-barang tjitakan, oepamanja: soerat-soerat OELEM, STAAT-STAAT, BRIEFKAART, VISITE KAARTJES dan lain-lainnja, hareplah memesen pada Drukkerij V.S.T.P. KARANGBIDARA atau SINAR-

\footnotetext{
${ }^{23}$ Tjokrosisworo, Kenangan, pp. 140-41. This feature in Lie Kimhok's grammar (Malajoe Batawie: Kitab deri hal perkataän Malajoe, hal memetjah oedjar-oedjar Malajoe dan hal pernahkan tanda-tanda batja dan hoeroef-hoeroef besar [Batavia: W. Bruining, 1884]) differs from the common practice of his day. Otherwise, he consistently spells in the same way as the system described.

${ }^{24}$ Van Ophuijsen, Kitab Logat Melajoe.

25/The newspaper Preanger Bode has posed the following question [Does Germany have the capability to invade England?], then has also given the answer at length that at the moment one cannot expect that Germany will be able to land its troops successfully in England" (my translation).

${ }^{26}$ Verslag Boedi Oetomo, Tahoen Kesepoeloeh 1917-1918 (Solo: Albert Rusche, 1919).

27 Mas Marco Kartodikromo, Sair rempah-rempah, vols. 1, 2 (Semarang: Sinar Djawa, 1918).

${ }^{28}$ Semaoen, Hikajat Kadiroen (Semarang: Kantoor P.K.I., 1920).
} 
DJAWA KAOEMAN-SEMARANG."29 Notice the spelling of soedara (SM saudara), "brother, second person pronoun"; tjitakan (SM tjétakan), "printed"; hareplah (SM haraplah), "please"; and memesen (SM memesan), "order." A similar example from somewhat later can be found in an advertisement for a hair oil produced by the Chinese drugstore Jo Tek Tjoe in Batavia published in the monthly women's magazine Doenia Kita (Batavia-Centrum, March 1938):

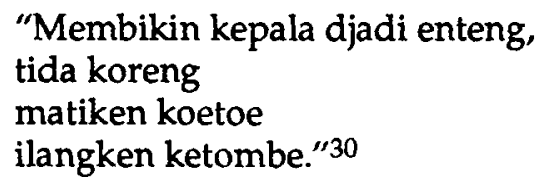

And if people think the ad is spelled that way because it was written by a Chinese, one notes the following advertisement for "Het Djamoehuis uit de Vorstenlanden" (The Herbal Medicine House from the Principalities), presumably owned by a Javanese merchant, which starts off with "Soepaja U tida kesalahan beli djamoe bikinan BETAWI, datenglah pada."31 Many other advertisements use similar nonstandardized orthography, which probably indicates that the business world did not pay too much attention to the standardized orthography.

One indigenous newspaper that almost consistently "flouted" the standardized orthography was Medan Prijaji, ${ }^{32}$ in which one can read passages such as the following:

Itoe semoea orang dapet taoe dengan membatja soerat kabar Pembrita Tjoeng Wa sebab ini soerat kabar ada pake bahasa Melajoe rendah, soeatoe bahasa jang gampang orang mengerti dan jang djadi bahasanja sebagian besar pendoedoek di Hindia Nederland (1909). 33

Barang kali kebanjakan Bopati tida dapet taoe jang Sripadoeka jang di pertoean Besar Gouverneur Generaal Idenburg ada di poedji dan di pertjajai oleh Santri-santri kita. (May 21, 1910).34

The fact that the standardized version of Malay was based on "Riau Malay" meant that Sumatran publications exhibited little of this nonstandardized orthography, at least in formal writing. However, one does find an interesting case in cartoons in the periodical Soeara

29 'Those of you who would like to make printed materials, for example: INVITATIONS, FORMS, POSTCARDS, VISITING CARDS and others, please order them at the V.S.T.P. KARANGBIDARA or SINAR-DJAWA Printing Press, KAOEMAN-SEMARANG" (my translation).

30"Makes your head feel light/prevents scabs/kills lice/gets rid of dandruff" (my translation). In standardized spelling, it would read: "Membikin kepala djadi enteng/tida' koreng/matikan koetoe/hilangkan ketombe." Note, however, the use of typically PIM vocabulary: membikin (SM memboeat) "make, cause" and enteng (SM ringan) "light."

31 "Lest you make a mistake buying herbal medicine made in BATAVIA, come to" (my translation). In standardized spelling, it would read: "Soepaja U tida' kesalahan beli djamoe bikinan BETAWI, datanglah pada."

32 At least in the issues available to me.

${ }^{33}$ (Cited in Salmon, Literature in Malay, p. 115) "Everyone can understand by reading the newspaper Pembrita Tjoeng Wa because it uses Low Malay, a language easily understood and the language of a majority of the population in the Netherlands Indies" (my translation). In standardized Malay orthography, it would read, "itoe semoea orang dapat tahoe dengan membatja soerat kabar Pembrita Tjoeng Wa sebab ini soerat kabar ada pakai bahasa Melajoe rendah, soeatoe bahasa jang gampang orang mengerti dan jang djadi bahasanja sebagian besar pendoedoek di Hindia Nederland."

34 "Perhaps most Regents cannot understand that His Excellency the Great Lord Governor General Idenburg has been praised and trusted by our Followers" (my translation). In standardized orthography, it would read "Barangkali kebanjakan Boepati tida' dapat tahoe jang Sripadoeka jang dipertoean Besar Gouverneur Generaal Idenburg ada dipoedji dan dipertajai oléh Santri-santri kita." 
berkala "Alhambra" (Roman jang modern), published in Belawan-Deli in the 1930s. The informal dialog in the cartoons includes sentences such as "Sobar2 adjélah ngobrol sampe" (SM Sabar2[?] adjalah ngobrol sampai), 35 which reminds one of Batavian/Jakarta Malay pronunciation.

It is somewhat ironic that whereas most indigenous nationalists quickly complied with the spelling introduced by the colonial government, it was actually the Chinese periodicals and books that remained in the nonstandardized orthography. Many examples can be cited, but to select at random, consider this excerpt from the Batavia-based Sin Po of July 1, 1914: "Dalem taon 1912 dalem soerat kabar N. Soer. Crt. ada dimoeat satoe protest atas hal kasi balik kombali ka Soemba itoe tiga radja Lowa jang diboewang." 36

A similar orthography was used by a Chinese newspaper, Han Po, published in Palembang, South Sumatra. This example from its first issue was dated November 8, 1926: "Dalem proefnummer kita soeda tida menerangken, kenapa kita poenja soerat kabar soeda dapetken itoe nama 'Han Po'? Disini kita rasa baek djoega kaloe pembatja bisa taoe." 37 Apparently, even in a place like Palembang in Sumatra, the nonstandardized spelling was also used by Chinese publishers.

During the Japanese occupation (1942-1945), when the regime encouraged the further cultivation of what was by then called Indonesian, the Chinese newspaper Kung Yung Pao continued to use the nonstandardized orthography, as in the following excerpt: "Berhoeboeng dengen diboekanja permoesjawaratan Kesoesastra'an Asia Timoer Raya jang ke II di Tokio pada tg. 25-26 Agoestoes 2603, Poesat Keboedajaan (Keimin Bunka Shidosjo) di Djakarta soedah mengirimken kawat oetjapan slamet salinannja dari bahasa Nippon."38

Chinese-published newspapers during the independence war era (1945-1949) also used nonstandardized orthography. In the first issue of the Semarang-based Sin Min (February 1, 1947), one can read the following introductory remark: "Djikaloe satoe soerat-kabar baroe sebagi Sin Min sampe boeat pertama kali di tangan pembatja, soeda samoestinja di antara berbagi-bagi pertanja'an jang timboel dalem hati pembatja adalah jang teroetama: Begimana haloeannja."39

\footnotetext{
${ }^{35}$ But this is definitely a moot point because the language is clearly so informal. However, this is brought up here to show that even in Sumatra one does come across nonstandardized orthography.

36"In the year 1912, in the newspaper N. Soer. Crt., a protest was published on the matter of the return to Soemba of the three exiled kings of Lowa" (my translation). In standardized orthography, it would read "Dalam tahoen 1912 dalam soerat kabar $N$. Soer. Crt. ada dimoeat satoe protest atas hal kasih balik kembali ke Soemba itoe tiga radja Lowa jang diboeang."

37 "In our trial issue, we have not explained why our newspaper has acquired the name Han Po.' Here we think it is good if the readers can know" (my translation). In standardized orthography, it would read "Dalam proefnummer kita soedah tida' menerangkan, kenapa kita poenja soerat kabar soedah dapatkan itoe nama 'Han Po'? Disini kita rasa baik djoega pembatja bisa tahoe."

38"In connection with the opening of the second assembly on Greater East Asian Literature in Tokyo on 25-26 August 2603, the Cultural Center (Keimin Bunka Shidosjo) in Djakarta has sent a congratulatory cable, whose translation from Japanese..." (my translation). Kung Yung Pao, August 23, 1943. Note the spelling of dengen (SM dengan), "with"; mengirimken (SM mengirimkan), "send"; slamet (SM selamat), "congratulations."

39"When a new newspaper like Sin Min reaches the readers for the first time, it is only natural that among the different questions that crop up in their minds, the foremost question will be What is its ideology like?" (my translation). In standardized orthography, it would read, "Djikalau satoe soerat-kabar baroe sebagai Sin Min sampai boeat pertama kali ditangan pembatja, soedah semestinja diantara berbagai-bagai pertanja'an jang timboel dalam hati pembatja adalah jang teroetama: Bagaimana haloeannja."
} 
Apparently, Chinese-published newspapers gradually standardized their orthography to conform to the 1947 Suwandi spelling system only after the transfer of sovereignty from the Netherlands to the Republic of Indonesia. Thus, in the February 24, 1950, issue of Keng Po, one can read the following: "Dalam pertemuan tanja djawab istimewa jang pertama diadakan sesudah penjerahannja surat-surat kepertjajaan kepada presiden Truman, duta besar Indonesia di Washington, Mr. Ali Sastroamidjojo, menerangkan kepada koresponden politik Aneta, bahwa ia tidak berpendapat kemadjuan komunisme di Asia akan mendjadi bahaja jang langsung bagi Indonesia." 40 However, another look at the advertising page again reveals nonstandardized spelling of words such as tida (standard Indonesian [SI] tidak), "not"; sampe (SI sampai), "arrive, until"; djato (SI djatuh), "fall"; and many others.

Thus, it is safe to conclude that in Java authors writing in romanized Malay orthography had initially used the same spelling system. After the establishment of the 1901 Van Ophuijsen spelling, however, most indigenous authors complied with this standardized spelling, at least in formal writing, whereas most ethnic Chinese authors only adapted their spelling system to the 1947 Suwandi Republican spelling after the transfer of sovereignty in 1949.

Despite this difference in orthography, the pronunciation of Indonesian has remained undifferentiated by speaker ethnicity to this day. Granted, some speakers of present-day Indonesian of Javanese language background, for example, do attempt to standardize or deJavanize their pronunciation, but the majority still speak Indonesian with a fairly strong Javanese accent. It is interesting to note that even some present-day Indonesian speakers from other regional language backgrounds are starting to pronounce the transitivizing/causative-benefactive suffix $-k a n$ as $[k \geqslant n]$. The author hypothesizes that this shift has been caused by the Javanese-accented pronunciation of national leaders of Javanese language background, such as Presidents Sukarno and Suharto, who pronounce forms ending in $[-\mathrm{aC}]$ as $[-\partial \mathrm{C}]$, such as in [dal $\partial \mathrm{m}]$ and [dat $\partial \eta$ ] instead of the standard forms [dalam] "inside" and [data门] "come." One might speculate that these non-Javanese are in a position to benefit most from loyalty to the regime.

With the increasing inclination of national leaders to speak off the cuff on the radio and television, one can hear the way they actually pronounce Indonesian. It is not uncommon for leaders who are in their fifties and sixties to show peculiarities often thought to be the sole property of PIM, as in words like [mis c h] (SI [masih] or [mas ( h] "still, yet") and [kal, ?] (SI [kalaळ] or [kaljo] "if, when"). Thus, the early PIM authors, whatever their ethnic background might have been, were spelling their Malay in a phonetically faithful way. It was, in fact, the new standardized spelling of Van Ophuijsen and later the Suwandi and 1972 spellings that did not represent PIM faithfully.

\section{The Morphology of Pre-Indonesian Malay}

One feature of PIM morphology is the dropping of the verb prefixes ber- 'stative' and meN- "active." Thus, in the reprint from the February 7, 1879, issue of Pembrita Betawi referred to previously, one finds phrases like orang njang maoe rampas aerlodjinja itoe toewan ${ }^{41}$ (a man who wanted to take the gentleman's watch by force), soepaja itoe toewan kaloewarin aerlo-

\footnotetext{
40"In a special press conference held after he handed over his credentials to President Truman, Indonesia's ambassador in Washington, Mr. Ali Sastroamidjojo, explained to Aneta's political correspondent that he did not think the progress of communism in Asia would become a direct danger to Indonesia" (my translation). By this time, no comment can be made on the orthography except that it complies fully with the Suwandi spelling.

${ }^{41}$ The SM equivalent would be orang jang maoe merampas arlodji toean itoe.
} 
djinja, ${ }^{42}$ (so that the gentleman took his watch out), Si rampok pegi tanja, ${ }^{43}$ (the robber went and asked). However, in the same excerpt one also finds full forms such as menampar, "slap." No certain way of generalizing is apparent to ascertain when the prefix ber- and meN- may be dropped.

One also sees a tendency to use prefixes interchangeably, even in the work of the same author, such as berdjawab and mendjawab "answer," or bernama and ternama, "be called, named." At times, one also finds hypercorrect forms such as berdoedoek (SM doedoek), "sit," and memakan (SM makan), "eat." The passive verb prefix di-, however, seems to be used properly, most likely because it carries a clearly different meaning in a sentence.

Another feature of PIM morphology is the use of the all-purpose transitive suffix -in, originally from Batavian Malay (e.g., kaloewarin, "take out" [SM keloearkan]). The fact that Batavian Malay has collapsed the two Malay suffixes $-i$ "locative" and - $k a n$ "causativebenefactive" 44 has meant that many authors tend to use them interchangeably, such as in segala orang boleh masoki di soerat chabar inie segala pemberitaan (all kinds of people may publish all kinds of news in this newspaper) and barang kali kita masoq-kan soerat pengadjaran (perhaps we shall publish educational writings). 45

But certainly every author-Dutch, Eurasian, Foreign Oriental, and indigenous-wrote this kind of Malay. After prescriptive grammars became available, those who were sensitive to language engineering tended to comply with them, but others seemed to ignore them almost altogether. Generally speaking, Chinese authors again tended to lag behind in complying with standardized Malay, and only after 1949 did they seem to standardize their morphology considerably.

Thus, as with phonology, one sees here a case wherein the colonial government, and later also the Republican government, prescribed a grammar that really did not represent the language used in everyday life.

\section{The Syntax of Pre-Indonesian Malay}

It is in the syntax of PIM that one finds agreement among many indigenous and most Chinese authors even after independence, in that both differed from the prescribed standard.

Both in Chinese and nationalist indigenous publications written by authors of Javanese language background, one finds syntactic constructions such as it $u$, "that," or ini, "this" + noun: for example, itoe toewan (SM toean itoe); "that gentleman"; the possessive constructions noun $_{2}+-n j a+$ pronoun $/$ noun $_{2}$ or noun $2+$ dari(pada $)+$ noun $_{2}$ or noun $n_{2}+(e m)$ poenja + noun 2 where noun 2 is the possessed and noun 2 is the possessor, for example, toean-toean empoenja Comité (SM Comité toean-toean), "your committee," and roemahnja toean Assistent-Wedono dari onderdistrict Semongan djoego (SM roemah toean Assistent-Wedono onderdistrict Semongan djoego) "the house of the assistant district head of the subdistrict Semongan Djoego." It should be mentioned here that authors even in nongovernment publications in Medan, North Sumatra, used this kind of syntax.

\footnotetext{
${ }^{42}$ The SM equivalent would be soepaja toean itoe mengeloearkan arlodjinja.

${ }^{43}$ The SM equivalent would be Si rampok pergi bertanja.

${ }^{44}$ Of course, spelled -ken by many authors.

${ }^{45}$ Soerat Chabar Batawie, April 3, 1858, reprinted in Tjokrosisworo, Kenangan, pp. 140-41. The SM equivalent would be segala orang boleh memasoekkan segala pemberitaan di soerat chabar ini and barangkali kita masoekkan soerat pengadjaran, respectively.
} 
One also finds the use in PIM of certain function words or conjunctions that differs from standard usage, such as the different use of ada in sentences like ini soerat kabar ada pake bahasa Melajoe rendah (this newspaper uses Low Malay) (SM soerat kabar ini memakai bahasa Melajoe rendah), and the different use of jang or njang in phrases like "bolée diharep jang Duitschland aken bisa menoeroenken" ([it] may be expected that Germany will be able to deploy) (SM boléh diharap[kan] bahwa Duitschland akan bisa menoeroenkan)

One should mention also the extensive use in PIM of a semipassive construction, such as in pekara [n]jang orang mengartie (issues that people understand) (SM perkara jang dimengerti orang). The "full" passive using the di- prefix is also used, however.

It is true that some Balai Poestaka-oriented publications, mostly written by indigenous authors but also by a few Chinese, did comply with the syntactic rules of standardized Malay. But this usage was perhaps indicative of the colonial establishment wanting to "purify" PIM by employing Sumatran editors, who were, supposedly, the real and pure speakers of Malay. Soeara Timoer, the magazine of the Perikatan Perkoempoelan Radio Ketimoeran (Association of Oriental Radio Organizations), a multiethnic association active in the early 1940s, was an interesting case in point. The editors and contributors of this periodical consisted of indigenous Indonesians and ethnic Chinese and Arabs. In its first issue (December 28, 1940-January 11, 1941), in the middle of articles written in standardized Malay, was an article by the Chinese Mrs. Tjoa Hien Hoeij; it is clear that the editors were trying to standardize her language, but apparently they found the job overwhelming and gave up after the first paragraph or so.

It is probably safe to conclude that more indigenous authors flouted the rules of standardized Malay in syntax than in orthography and morphology. With education in standardized Indonesian after independence, syntactic constructions peculiar to PIM tended to disappear in formal discourse.

However, a cursory look at the colloquial language of modern Indonesia reveals that many people still use the syntax of PIM. In fact, as late as the mid-1960s one could still find someone like Sukarno speaking off the cuff and using PIM syntax. The same can be said about the unrehearsed language of President Suharto and other officials today. It is interesting that now some people complain about the so-called bahasa pejabat, "officialese," with features like the excessive use of daripada, "of, possessive marker." The recent popularity of the use of noun/adjective + punya among trendy youths bears witness to the pervasive influence of PIM.

\section{The Vocabulary of Pre-Indonesian Malay}

The vocabulary of PIM contains words that are spelled or pronounced differently in SM, such as belon or beloen (SM beloem), "not yet"; koetika (SM ketika), "when" (as a conjunction); kombali (SM kembali), "return"; and misih (SM masih), "still, yet." A few words have a different meaning in PIM; for example, PIM koetika means "chance, opportunity" in addition to "when" (as a conjunction), which is its sole meaning in SM.

PIM also uses words that are considered colloquial or nonstandard in SM, such as kasilh], "give" (SM beri) and bikin, "make, do" (SM boeat, kerdjakan). Incidentally, these PIM words are used in combination with other words to signify the causative as in kasi[h] lihat, "cause to see (i.e., show)" and bikin betoel, "cause to be in order (i.e., repair)." The same causative meaning is expressed in SM with the suffix -kan and/or the prefix per- (thus, per + lihat +kan for kasilh] lihat; mem +betoel +kan for bikin betoel). One should note, however, that 
such PIM words have survived in the spoken language and in the past fifteen years or so have been revived by publications like Tempo magazine.

The main difference between a PIM vocabulary and that of SM is the freer borrowing from other languages one finds in PIM. PIM generally borrows more freely from Javanese and Dutch, whereas in the SM of Balai Poestaka publications, one notices a conscious attempt to avoid using loan words whenever possible. More accurately, one must point out that the Balai Poestaka editors, many of whom had a Minang language background, tended to borrow from that language as well. One can then argue that whether from Javanese or from Minang, PIM or SM does borrow vocabulary items.

When one takes into account the existence of borrowed words, one may say that there are subdialects of PIM, in the sense that ethnic Chinese authors tend to sprinkle their Malay with borrowings from Hokkien Chinese. Only in this context can one speak of a "Chinese Malay" or a Chinese subdialect of PIM. But perhaps, then, one must also speak of a "Javanese Malay" or "Arab Malay" as subdialects because these groups also borrow from their original languages.

What many people mistakenly call "Chinese-Malay," structurally and in formal language use, has only been a variety of Malay/Indonesian (pre-Indonesian Malay) widely used by the bourgeoisie in colonial urban centers.

The Chinese of Java, together with other bourgeois population groups in the colony, did develop a mixed colloquial Javanese-Malay language. But it should be emphasized that the Chinese were not the only group to have done that. In fact, now more and more Javanese families are doing so, too.

\section{Pre-Indonesian Malay and Modern Indonesian: The Social Dynamics of Language Development}

One sees then how PIM started as the lingua franca of different groups in the colony's urban society. The colonial government, however, planned to purify this variety of Malay, ${ }^{46}$ and the culmination was the establishment of the 1901 Van Ophuijsen spelling and the ensuing standardization efforts of the Balai Poestaka.

If one considers the instances described in the preceding section, one may conclude that the results of the colonial effort were largely as follows:

1. In orthography, many indigenous authors did comply, but Chinese authors did not do so until after 1949.

2. In morphology, syntax and vocabulary, however, only those authors whose works were actually published by official publishing houses, mainly Balai Poestaka, showed signs of compliance. Most of these authors were indigenous; many were of Sumatran origin. Chinese authors and indigenous nationalists of Javanese language background retained the use of features typical of PIM, which were stigmatized by the colonial linguistic and literary establishment.

Ironically, after independence the Balai Poestaka variety continued to be regarded as standard Indonesian. However, in Java, preindependence Malay. has survived in informal and intimate speech. Java Indonesian has had different subvarieties. If one concentrates on just the variety used by those with Javanese language background, one finds that both eth-

${ }^{46} \mathrm{Cf}$. John Hoffman, "A Foreign Investment: Indies Malay to 1901," Indonesia 27 (1979): 65-92, passim. 
nic Javanese and Chinese use basically the same variety in interethnic encounters. But when one examines the domains of language usage, one finds differences.

The Chinese of Java, who adopted Malay earlier than most indigenous speakers, developed a mixed Javanese-Malay home language when most indigenous families still spoke Javanese at home. This mixed language was not used exclusively by the Chinese. Eurasians and other Foreign Orientals, such as Arabs and ethnic South Asians, who participated in bourgeois, colonial life, also used it in their homes. As noted previously, commercial advertisements in indigenous publications tended to use nonstandardized Malay although standardized Malay, was used throughout the text. Similarly, in business circles people use nonstandardized Indonesian with heavy Javanese influence. Especially in the marketplace and retail shops, indigenous traders and employees use the mixed Javanese-Malay variety.

In more formal domains, everyone tries to speak a variety of Indonesian as close as possible to the prescribed standard. Failure to meet the standard is usually because the speaker has not been educated in the postindependence system, in which standardized Indonesian has been the medium of instruction. It may be true that some Chinese have been less concerned about standardizing their Indonesian, but the same can also be said about quite a few Javanese.

With the increasing modernization and capitalization of Indonesian life, more and more urban, middle-class, indigenous families in Java-and apparently elsewhere-are adopting Indonesian as the home language. ${ }^{47}$ In Javanese-speaking areas, this means that for the first time, these families are using Indonesian and Javanese side by side in the home. Interestingly enough, but perhaps not surprisingly, the type of Javanese-Malay/Indonesian mixture that has long been spoken at home by Eurasians, Chinese, and Arabs can now also be heard in Javanese families. It is remarkable that one Javanese grandmother commented on how her children and grandchildren are speaking "like Chinese" (koyok Cino).

It is, then, another irony that as many Chinese families are becoming better educated in the Indonesian system and, hence, adopting a variety of Java Indonesian in the home that is closer to the standardized norm, more and more middle-class Javanese families are acquiring the variety stereotypically labeled "Chinese Malay" or "Chinese Indonesian."

In Java, then, and perhaps in other areas, such as Madura, Bali, and elsewhere, where the indigenous population mostly spoke a regional language, the Chinese of Indonesia have played a significant role in the development of modern Indonesian; they have been by far the largest group to communicate in a variety of Malay, admittedly not the one condoned by the colonial government, which later developed into a specific variety of modern colloquial Indonesian. Their role is, of course, more significant if one considers that with Malay they provided their own group as well as others in both pre- and postindependence Indonesia with a literature, a press, and various genres of performing arts more accessible to the general population than those provided by the colonial government.

${ }^{47}$ See Dédé Oetomo, “Bahasa Indonesia dan Kelas Menengah Indonesia,” Prisma 18 (1) (1989): 17-29. 


\section{Appendix 1 \\ Corpus Materials}

\section{Periodicals}

Bintang Barat (Batavia), 1.iv.1879 (reprinted in Jayakarta, 11.vi.1990).

Doenia Achirat (Fort de Kock), 19.x.1923.

Doenia Kita (Batavia-Centrum), Maart 1938.

Han Po (Palembang), 8.xi.1926.

Indonesia Raja (Batavia-Centrum), December 1937.

Isteri Indonesia (Batavia), no. 6, June 1939.

Kaoem Moeda (Bandoeng), 2.i.1915.

Keng Po (Batavia/Djakarta), 4.ii.1931, 3.xi.1940, 2.i.1947, 12.vii.1947, 24.ii.1950.

Kung Yung Pao (Djakarta), 23.viii.1943.

Medan-Prijaji (Batavia), 1909, 21.v.1910.

Mimbar Indonesia (Djakarta), 10.xi.1947.

Palembang Sinboen (Palembang), 7.xi.1944.

Patriot (Jogjakarta), 23.v.1946.

Pembrita Betawi (Batavia), 7.ii.1879 (reprinted in Jayakarta, 6.vi.1990).

Pewarta Pertoekangan ("Het Ambachtsblad") (Jogjakarta), 5.iv.1937.

Siasat (Djakarta), 14.vi.1947, 28.ix.1947.

Sin Min (Semarang), 1.ii.1947, 16.vii.1956.

Sin Po (Batavia/Djakarta), 1.vii.1914, 18.ii.1919, 1.vii.1924, 2.vii.1924, 2.vii.1930, 3.vii.1930, 15.ii.1935, 15.vii.1939, 2.i.1953, 2.i.1958.

Sin Po Oost-Java/Sin Tit Po (Soerabaia), 1.vii.1922, 16.xii.1941.

Soeara Berkala “Alhambra" (Roman jang modern) (Belawan-Deli), no. 2, ca. 1930.

Soeara Oemoem (Djakarta), 4.ii.1947.

Soeara Timoer - Madjallah PPRK (Perikatan Perkoempoelan Radio Ketimoeran) (Batavia), 28.xii.1940, 11.i.1941.

Soeara Tsing Niën (Batavia), no. 10, 1937.

Warta Bhakti (Djakarta), 2.i.1963.

\section{Monographs}

Commissie voor het adatrecht. "Perdjandjian dèsa dalam kaboepatèn Sidoardjo." In Adatrechtbundel II (Java en Madoera), pp. 272-85. The Hague: Nijhoff, 1911.

Kartodikromo, Mas Marco. 1914. Mata gelap: tjerita jang soenggoeh kedjadian ditanah Djawa, pt. 3. Bandoeng: Drukkerij Insulinde.

—. Sair rempah-rempah. Vols. 1, 2. Semarang: Sinar Djawa, 1918.

. Persdelict dan soerat perlawanan dari Marco Kartodikromo (di persidangan oemoem Landraad Djokjakarta pada hari Kemis 8 December 1921 dengan poetoesan vonnis tanggal 8 December 1921, no. 989/1921). Yogyakarta: Tijp. Sneldrukkerij Pakoealaman, 1922.

Meursinge, A. Maleisch leesboek voor eerstbeginnenden en meergevorderden. 2d ed. Leiden: S. en J. Luchtmans, 1845.

"Patriot" Cheribon. Siapa Dia Itoe? Gadis Bangsawan Indonesia atau Hati Wadja. Palembang: Raden Bratanata/Pertja Selatan, $\mathbf{n}$. d.

Pramoedya Ananta Toer, ed. Tempo Doeloe: Antologi Sastra Pra-Indonesia. Jakarta: Hasta Mitra, 1982.

Semaoen. Hikajat Kadiroen. Semarang: Kantoor PKI., 1920.

Sukarno. Dibawah Bendera Revolusi, vols. 1, 2. Jakarta: Panitya Penerbit Dibawah Bendera Revolusi, 1959-1964.

Verslag Boedi Oetomo, Tahoen Kesepoeloeh 1917-1918. Solo: Albert Rusche, 1919. 